\title{
AOR
}

Selected Papers of \#AoIR2021:

The 22nd Annual Conference of the

Association of Internet Researchers

Virtual Event / 13-16 Oct 2021

\section{PLATFORMIZING DELIVERY WORKERS' EXPERIENCES: BUILDING WORKER-OWNED PLATFORMS IN BRAZIL, SPAIN AND FRANCE}

\author{
Rafael Grohmann \\ Unisinos University, Brazil
}

The article aims to analyze the emergence of worker-owned platforms, specifically delivery workers' experiences, as one of the laboratories of platform labor (Cant 2019, Casilli \& Posada 2019) and the circulation of workers' struggles (Englert, Woodcock \& Cant 2020). Drawing on interviews with six cases in three different countries (Spain, France and Brazil), the research highlights the commonalities, specificities and challenges of platformizing delivery workers' experiences in different countries.

Previous literature on platform labor has emphasized that workers create tactics and strategies to interact in everyday work (Sun 2019). Workers' discontentment with dominant platforms served to create and strengthen emerging solidarities (Soriano \& Cabanes 2020) in associations and unions, but it has also led to the creation of workerowned platforms using different institutional designs, especially what has become known as platform cooperativism (Scholz 2016).

Since 2016, research on platform economy has shown the possibilities (Schor 2020, Pazaitis, Zhu \& Marjanovic 2020) and the limitations (Sandoval 2019, Cant 2019) of platform cooperativism. Furthermore, platform cooperativism has a specific legal profile. But the principles of worker ownership in the context of platformization do not necessarily appear under the label "cooperative." Building worker-owned platforms includes, but is not restricted to, platform cooperativism. At the forefront of all this is achieving democratic labor relations and worker ownership in processes that can be amplified by digital platforms, with possibilities for the circulation of the common (De Peuter \& Dyer-Witheford 2010). These initiatives can be based on platforms (with their own infrastructures) or supported by platforms (not necessarily with worker-owned infrastructures) (Morell, Espelt \& Cano 2020).

As experiments, these initiatives offer no ready formula and have different characteristics and elements depending on their sector or location. At least 30 new delivery collectives and cooperatives have emerged in recent years. The sample of this

Suggested Citation (APA): Grohmann, R., (2021, October). Platformizing Delivery Workers' Experiences: Building Worker-Owned Platforms in Brazil, Spain And France. Paper presented at AoIR 2021: The 22nd Annual Conference of the Association of Internet Researchers. Virtual Event: AolR. Retrieved from http://spir.aoir.org. 
research is: Mensakas (Barcelona, Spain), Rodant (Valencia, Spain), Resto.Paris (Paris, France), Coursiers Bordelais (Bordeaux, France), Senõritas Courier (São Paulo, Brazil), and Pedal Express (Porto Alegre, Brazil). The analysis highlights the following dimensions: productive processes and work organization, technological challenges and platform building, the use of social media to communicate with and organize workers, and the future of worker-owned platforms.

Except for Pedal Express, founded in 2010, all other initiatives were created within the context of platform economies beginning in 2017. This situate them as emerging collectives circulating different logics focused on workers and sustainability reacting against dominant platforms. Another reason for choosing these initiatives was their diversity. Some are the product of union struggles, while others are focused on gender equality, especially women and LGBTQI+, and find themselves in varying stages of development in different cities of different sizes.

Worker-owned experiences we analyzed are from three different countries, two in Europe and one in South America. On one hand, these experiences present specific social and political contexts. In 2020, Brazil experienced its largest riders' strike that led to worker-owned initiatives having more visibility. The platformization of riders' experiences is still not a big issue. Additionally, if they do create their own platforms, they do not want to be dependent on software that does not follow bottom-up logic or that does not dialogue with their local realities and needs. In Europe, the Spanish coops were born from the union struggles, while French initiatives are related to CoopCycle, the federation of cooperatives that has strengthened relationships with worker groups in South America. Thus, the construction of their own platforms is something closer to becoming a reality, or, in fact, it is already a reality.

On the other hand, these experiences reinforce the transnational characteristics of confronting the platformization of labor and the potential for circulating workers' struggles. Thus, despite the different contexts, we emphasize that these experiences have connections. They are all initiatives under construction, whether with regards to work organization or to using social media to communicate with workers and clients and to promote themselves using media strategies and digital presence, even though most social media is owned by big platforms.

The workers do not agree with the idea that building worker-owned platforms is only a question of technology, understanding that it also presents financial and organizational issues. What is important is building worker-owned productive processes first. In this sense, horizontal management and department divisions where all workers have a voice are key aspects of workplace democracy. The initiatives emphasize that productive processes are under constant construction and that horizontality is not without disputes and contradictions.

CoopCycle plays a fundamental role in providing a platform for co-ops to use, although it is not necessarily "from below", as observed in Resto.Paris' requests for improving user experiences and company relationships. Although CoopCycle has less dialogue with Brazilian initiatives, it also plays a key role in connecting and articulating other coops. 
Workers understand that their relationship with social media for communication purposes and for work organization is essential, but that there is no ready formula on how to use it. Several social media platforms are still being used experimentally. Most social media is proprietary, especially in Brazil where WhatsApp is widely used.

Platformizing worker-owned initiatives is not something follows a predefined model or that is necessarily related to a concept. They are diverse and have specific relationships with digital presence. Understanding diverse worker-owned possibilities also implies avoiding simply replicating certain models that have been successful in, for example, Europe. Delivery workers' experiences in Brazil show a potential for work organization and for communicating between workers that goes beyond the preestablished definitions of how these initiatives should be.

\section{References}

Cant, Callum. 2019. Riding for Deliveroo: Resistance in the New Economy. London: Polity.

Casilli, Antonio, and Julian Posada. 2019. "The Platformization of Labor and Society". In Society and the Internet, edited by Mark Graham and William Dutton, 293-305. Oxford: OUP.

de Peuter, Greig and Dyer-Witheford, Nick. 2010. Commons and Cooperatives. Communication Studies Faculty Publications. 15.

Englert, Sai, Jamie Woodcock, and Callum Cant. 2020. Digital workerism: Technology, platforms, and the circulation of workers' struggles'. tripleC: Communication, Capitalism \& Critique, 18(2020), 132-145.

Geelan, Torsten, and Andy Hodder. 2017. Enhancing transnational labour solidarity: the unfulfilled promise of the Internet and social media. Industrial Relations Journal, 48 (4), 345-364.

Huws, Ursula. 2020. Reinventing the Welfare State: Digital Platforms and Public Policies. London: Pluto.

Morell, Mayo Fuster, Ricard Espelt, and Melissa Renau Cano. 2020. Sustainable Platform Economy: Connections with the Sustainable Development Goals. Sustanability, 12 (8), 7640 . 
Pazaitis, Alex, Vasilis Kostakis, and Michel Bauwens. 2017. Digital economy and the rise of open cooperativism: the case of the Enspiral Network. Transfer: European Review of Labour and Research, 23 (2).

Sandoval, Marisol. 2019. Entrepreneurial activism? Platform cooperativism between subversion and co-optation. Critical Sociology. Online First, 2019.

Scholz, Trebor. 2016. Platform Cooperativism: Challenging the Corporate Sharing Economy. New York: Rosa Luxemburg Stiftung New York Office.

Schor, Juliet. 2020. After the Gig: How the Sharing Economy Got Hijacked and How to Win It Back. Berkeley: University of California Press.

Soriano, Cheryll, and Jason Cabanes. 2020. Entrepreneurial solidarities: Social media collectives and Filipino digital platform workers. Social Media + Society. Online First.

Sun, Pin. 2019. Your order, their labor: An exploration of algorithms and laboring on food delivery platforms in China. Chinese Journal of Communication, 12(3), 308-323. 